\title{
OWNERSHIP CONCENTRATION, CORPORATE LIQUIDITY, AND DIVIDEND PAYMENT POLICY: EVIDENCE FROM INDONESIAN FINANCIAL INDUSTRIES
}

\author{
Antonius Siahaan* \\ Swiss German University \\ Yosman Bustaman \\ Swiss German University \\ Indah Larisa Sari \\ Swiss German University
}

\begin{abstract}
The main objective of this research is to analyze the effect of ownership concentration and corporate liquidity on dividend payment policy in the Indonesian financial industry. Dividend payment is measured using dividend pay-out ratio on measuring dividend payment. Corporate ownership concentration is measured using the number of shares held by legal individual investors and large block shareholders. Ownership concentration is divided into three categories, which are inside shareholders, stable shareholders, and market shareholders. Corporate liquidity is measured by corporate profit, defined by retained earnings/total assets and retained earnings/total equity, corporate leverage (total liabilities/total assets), and corporate size (log normal total assets). We apply data panel regression and the robust least square method. Based on the robust least square method of testing data panel regression, we find there is a relationship between insider shareholder, market shareholder, and dividend payment policy. In contrast, there is no relationship between stable shareholder and dividend payment policy. We also found a relationship between corporate profit, which variable is retained earnings/total assets, corporate leverage, and corporate size, and dividend payment policy. These results lead to the conclusion that dividend payments increase when ownership by inside shareholders decreases, and that when ownership by market shareholders increase corporate profit will also increase, and corporate leverage and corporate size decreases.
\end{abstract}

Keywords: dividend payment policy, ownership concentration, corporate liquidity.

Received: 29 January 2019

Accepted: 11 June 2020

\section{INTRODUCTION}

Dividend payment policy provides relevant information about a firm's liquidity and corporate governance. Through its dividend payment policy, which shows the asymmetry between corporate

\footnotetext{
- Corresponding author: Swiss German University, Prominence office Tower- J1 Jalur Sutera Barat No 15 Alam Sutra, Tangerang 15143 Indonesia; Tel : (+622129779597); Email: antonius.siahaan@sgu.ac.id; antonius.siahaan1@gmail.com
} 
insiders and outside shareholders, a firm with different levels of shareholder protection signals its potential growth opportunities or prospects to the financial market (Esqueda, 2016). Similar to the study by Watts (1973, cited in Esqueda, 2016), Esqueda shows that dividend payment provides information about the expected future cash flows of the corporation.

Koussis, Martzoukos, and Trigeorgis (2016) in their study stated that the retained earnings are acquired as liquid assets that earn a specified interest periodically and can be used to decrease external financing in the future and guard against incurring bankruptcy costs and costly default risk. This study contributed to the explanation of the negative disincentive effect to save as cumulated cash savings, which can be lost at default regarding considering limited liability and quantifying the trade-off between the standard cost of savings and other important offsetting benefits. According to this study, default risk cannot be avoided if it depends only on corporate retained earnings with low initial cash balances and low profitability. In this case, if external financing will be needed in the future, it is better to pay shareholders higher dividends and reduce cash balances. In contrast, for highly profitable corporations and those with high initial cash balances, the negative role of retained earnings is reduced as default risk decreases, because the accumulation of cash balances can be used to finance growth and decrease expensive external financing.

Other findings that explain how relevant information on corporate liquidity is contained in dividend payment policy is shown in Fama and French's (2000) study. According to Fama and French (2000), relevant information in the dividend payment policy appears as the corporation's dividend pay-outs, which are related positively to corporate profitability and size, and conversely to growth opportunities. They also reported the empirical finding that corporations with higher profitability with lower growth opportunities pay higher dividends. This finding is known to mitigate agency problems. In this case, good corporate governance roles on the mechanism to increase dividend pay-out also to solve the agency problems. Jensen (1986) suggests in his free cash flow theory that dividend payment reduces the resources under a manager's control to be used ineffectively or to be used for his own benefit through vast accumulated cash balances and making it similar act as managers monitor the capital markets when they are looking to raise funds.

Some evidence has been taken from studies in different countries to explain the relationship of corporate governance and corporate liquidity to dividend payment policies. One such study in the United States, by Esqueda (2016), showed cross-listing events as the cause of improvements in corporate governance. His study also emphasized the link between corporate governance signalling and its effect on dividend payment policy. He found that the corporation's dividend policy will reach a new equilibrium when the level of shareholder protection is shifted and pre-cross-listing control determines the direction of the dividend adjustment. Exchange-traded cross-listings are established to reduce dividend payments as they replace dividends with better corporate governance. Increasing dividend distribution and payment is executed when cross-listings are controlled by insiders. Mitton (2004) in his study suggested that firms with stronger corporate governance perhaps have a higher dividend payment after cross-listing. Therefore, the cross-listing level and ownership structure in the United States interprets useful information regarding future shifts in dividend payments. Corporations in common law countries such as the United States, countries with better protection of minority shareholders, pay higher dividends (LaPorta, LopezDe-Silanes, Shleifer, \& Vishny, 2000). Coffee (2002) shed light on cross-listing in the United 
States that empower investors from foreign corporations to effectively apply U.S. securities laws and enforce the mechanisms to induce dividend payment to be increased.

In contrast, according to Coffee (2002), one of Europe's markets, the London Stock Exchange (LSE), unilaterally started to quote the major European-listed stocks and quickly gained a dominant share of the European stock exchanges in the late 1980s. Additionally, Petrasek (2012) found in his study that the LSE, similar to major U.S. exchanges, provides corporations with liquid markets for fund raising. Conversely, cross-listing in London does not force foreign corporations to comply with the U.K. legal rules. Therefore, regarding market liquidity, there are changes in dividend payment policies after cross-listing on the LSE. The U.S. and U.K. markets are similar in their stock ownership. Gugler and Burcin Yurtoglv (2003) found stock ownership in the U.S. and U.K. is often spread out and it is proven that each individual shareholder only has limited incentives and ability to monitor the management. Furthermore, in Continental Europe, a concentrated ownership structure is the distinguishing feature, and corporate law plays a minor role. Large shareholders hold the main control of management. With this type of ownership structure, conflict arising between the large controlling shareholders and small minority shareholders is still possible. The legal protection of minority shareholders is a problem in these governance systems.

Market characteristics and corporate governance structures in different countries are different, such as in Anglo-Saxon countries (the United States and United Kingdom) and in Continental Europe like Germany, and also in Japan and most of the Southeast Asian countries. Gugler and Burcin Yurtoglv (2003) showed that in Japan and most of the Southeast Asian countries, including Indonesia, the large blockholders dominate the ownership structure of corporations. In Indonesia the level of ownership structure and profitability of public manufacturing companies affect the dividend pay-out policy (Akbar \& Bustaman, 2019). For our study, we chose the Indonesian case because, first, few articles have been published that discuss dividend policy for Indonesian companies. Among them, Mulyani, Singh, and Mishra. (2016) and Setia-Atmaja, Tanewski, and Skully (2009) analyzed the effect of family ownership on dividend pay-out policy. Second, the financial industry plays an important role in contributing to the Indonesian economy. Third, Indonesia applies different rules and regulations on the protection of shareholders as well as different tax laws with other countries, which have an effect on dividend policy (LaPorta et al., 2000). In this type of ownership structure, the legal requirements for management, often part of the controlling family, are rather weak. This model of ownership will face a lack of investor protection because owners who are not protected from the controlling owner will seek to protect themselves by becoming the controlling owner.

Therefore, although every country has different market characteristics, different ownership structure or corporate governance, problems deciding dividend payment policies are probably similar. The minority shareholder, who is usually a market (public) shareholder and owns less than five percent of stock, has limited ability to control the corporation's management and large shareholders tend to control the management and influence the dividend payment policy.

\section{LITERATURE REVIEW AND HYPOTHESIS DEVELOPMENT}


Dividend is defined as a cash distribution of earnings to the shareholder and it is decided by the board of directors. The term distribution is preferred to dividend if a distribution is executed from sources other than current or accumulated retained earnings. However, a dividend is a distribution from earnings and a liquidating dividend is a distribution from capital in a corporation (Ross, Westerfield, Jaffe, Lim, Tan \& Wong, 2015).

Different types of dividend include regular cash dividend, extra-cash dividend, liquidating dividend, and stock dividend. Regular cash dividends are the most common and are usually paid by public companies two to four times a year; when corporations pay a cash dividend, they reduce corporate cash and retained earnings. A liquidating dividend reduces corporate capital. Another type of dividend is stock dividend. A stock represents a claim on the corporation's assets and earnings. A stock dividend is not regarded as a true dividend since no cash is paid by the firm. A stock dividend reduces the value of each share and is commonly expressed as a ratio. For example, with a two percent stock dividend, a shareholder receives one new share for every fifty currently owned (Ross et al., 2015).

Hypothesis $1 a$. There is a statistically significant negative effect of inside shareholding on dividend payment policy.

Corporate governance is different across countries. Broadly, in financial systems it is shaped by the quality of legal rules which will protect the outside, not controller or public investors (Bukart \& Panunzi, 2005). Concentration of ownership has a positive impact on corporate performance in countries where the inefficiency is found in their legal protection of minority shareholders. Concentration of ownership is defined by the number of stocks owned by legal individual investors and large block shareholders. Thus, ownership concentration becomes an efficient corporate governance strategy (Heugens, Van Essen, \& Van Oosterhout, 2008; Esqueda, 2016; Spamann, 2010).

Heugens et al., (2008) cited two governance strategies regarding shareholders' investment protection and their residual earnings. First, the disciplinary force of external governance systems, such as the legal systems and capital markets, protects against expropriation by controlling shareholders or managerial opportunism (Gillan, 2006; Walsh and Seward, 1990 cited in Heugens et al., 2008). Second, if ownership is concentrated, such shareholders can directly influence top managers to run the corporation in their interest (Coffee, 1991 cited in Heugens et al., 2008). This second governance strategy is supported by the study of Jensen and Meckling (1976), who found that expropriation by controlling shareholders or managerial opportunism can be limited by the expenditure of resources to monitor the activities of outside stockholders.

In most Asian corporations, shareholders want to take part in monitoring the firm, which they can only execute effectively if they increase their equity holdings. Shareholders have powerful incentives to be involved in governance by concentrating their ownership, as well as a tool to influence managers by means of direct access and also the threat of using their concentrated voting rights strategically (David, Hit, and Liang, 2007 cited in Heugens et al., 2008). Thus, concentrated shareholders stimulate the corporate leadership to work in their interest and this is positively related to corporate performance. It means the corporation gains more retained earnings. 
According to Gerlach (1992) in Heugens et al., (2008), there are three types of shareholders involved in ownership concentration: stable owners, inside owners, and market owners. Each of these groups tends to have distinct investment objectives resulting in differential performances. Inside shareholders are individuals or groups who combine a substantial equity stake with direct managerial control over the firm. In Asia inside owners tend to consist of corporate founders and their immediate families rather than professional managers. In Indonesia, inside shareholders in banking are based on financial service authority (OJK) regulation number 39/POJK.03/2017 about single ownership in Indonesian banking on first article, verse three, four, and five. Verse three states that a controlling shareholder is a legal entity and/or an individual and/or a business group that: a. owns a bank share of $25 \%$ or more of the total shares issued by the bank and has voting rights; b. has a bank share of less than $25 \%$ of the total shares issued by the bank and voting rights but may be proven to have controlled the bank either directly or indirectly. Inside shareholding in a corporation in Indonesia is regulated in the decision of the chairman of the capital market supervisory body and financial institution (Bapepam \& LK, 2011) regarding the takeover of public corporations. Article 1, point c states that the controller of the corporation is an individual or companies who own more than $50 \%$ of the total paid up shares, or a person who has the ability to determine, directly or indirectly, in any way the management and/or discretion of the public corporations.

Hypothesis $1 b$. There is a statistically significant positive effect of stable shareholding on dividend payment policy.

Stable shareholders, such as banks and insurance corporations, characteristically have multiple ties with the corporations they own. They are often also creditors, buyers, debtors, suppliers, or alliance partners. Their equity stake primarily serves to seal an often-complex set of non-shareholder relationships with the corporation and is often reciprocated to create cross-holdings (Roe, 1994 in Gerlach 1992 in Heugens et al., 2008). Regarding the relational multiplicity, profitability objectives are typically only a secondary consideration for stable shareholders, although it also makes them very sensitive to pressures from the focal firm's management (Heugens et al., 2008).

Hypothesis 1c. There is a statistically significant positive effect of market shareholding on dividend payment policy.

Market shareholders are different from stable and inside investors in that they are typically tied to the corporation only with their equity stakes and mostly operate at arm's length from the corporation's management. Thus, market shareholders tend to have maximal equity returns as their primary investment objective (Fukao, 1999 cited in Heugens et al., 2008). Corporations may pay much attention to the pressures of market shareholders for two reasons. First, market investors will not hesitate to sell their ownership stake when they are dissatisfied with the firm's share performance. This is a powerful disciplining force, since selling off large blocks of shares is likely to lower the firm's share price and thus increase its cost of equity capital. Second, market investors will factor in a risk premium when they get attention in tunnelling or managerial entrenchment and it makes corporation's cost of equity capital increase. It forces corporate managers to engage in strategies consistent with satisfying market shareholders, which will cause them to outperform firms owned by either inside or stable shareholders. 
Hypothesis $2 a$. There is a statistically significant positive effect of retained earning divided by total assets (corporate profit) on dividend payment policy.

The term liquidity is defined as how easily and quickly, without significant loss in value, one asset can be converted to cash (Ross et al., 2015). Thus, corporate liquidity can be defined as the ability of a corporation to pay its debts or its obligations using its liquid assets. The most liquid asset is cash. Shares of stock (in stakeholder equity) also can be quietly liquid, because they can be easily sold in the capital market.

Corporations adopt dividend policies that best fit where they currently operate in their life cycles. For instance, high-growth corporations with great investment opportunities do not usually pay dividends. Stable corporations that are liquid with larger cash flows and fewer projects, or where retained earnings are a large portion of total equity (and of total assets), usually pay dividends and decreases to near zero when most equity is contributed rather than earned. This type of corporation tends to pay more of its earnings out as dividends.

DeAngelo, DeAngelo, and Stulz (2006) stated that dividends tend to be paid by mature, established firms, while young firms face relatively more investment opportunities but their resources are limited so that retention dominates distribution, whereas mature firms are better candidates to pay dividends because they have higher profitability and fewer attractive investment opportunities. and French (2000) found that firms with high profitability and low growth rates tend to pay dividends, while low-profit and high-growth firms tend to retain any profits.

DeAngelo et al., (2005) tested the life cycle theory by assessing whether the probability that a corporation pays dividends is positively related to its mix of earned and contributed capital. They also examined whether a corporation that is profitable, with relatively high retained earnings as a proportion of total equity (RE/TE) and of total assets (RE/TA), is more likely to pay dividends. DeAngelo et al., (2005) indicate the probability that a corporation pays dividends increases with the relative amount of earned equity in its capital structure. The proportion of dividend payed is high when earned equity is a large fraction of total assets, and decreases as RE/TA declines. Their findings also indicate that a corporation's earned/contributed capital mix (not its total equity, but also debt-to-equity mix) is a key determinant of its decision to pay or not pay dividends.

Hypothesis $2 b$. There is a statistically significant positive effect of retained earnings divided by total equity (corporate profit) on dividend payment policy.

In the capital start-up stage corporations tend to have low RE/TE (RE/TA), whereas, more mature corporations with ample cumulative profits tend to have high RE/TE (RE/TA) and that makes them largely self-financing. Hence, this type of corporation becomes a good candidate for paying dividends. The proportion of equity capital that is earned is conceptually different from current or short-term profitability, which is widely recognized to affect dividend decisions. It is also a better measurement of a firm's life cycle stage than its cash balances, because the source of the cash impacts the dividend decision. For example, high cash holdings can reflect the proceeds of a recent equity offering for a firm whose low RE/TE and RE/TA show it to be in the start-up rather than the mature stage. 
Hypothesis 2c. There is a statistically significant positive effect of corporate leverage on dividend payment policy.

The definition of leverage is the use of various financial instruments or borrowed capital to meet a corporation's long-term ability to pay its obligations/debts or to finance assets, or to increase the potential return of an investment. In other words, leverage helps a corporation by adding more liquid assets.

Hypothesis $2 d$. There is a statistically significant positive effect of corporate size on dividend payment policy.

DeAngelo et al., (2005) indicated that corporation size, current and lagged profitability, leverage, growth, cash balances, and dividend history are controlled using a broad variety of multivariate logit specifications. They consistently observed a positive and highly significant relationship between the probability that a corporation pays dividends and its earned/contributed capital mix.

The corporation size is calculated using the log normal of total assets. It means vaster corporate total assets and larger corporate size. Whether the corporation is more liquid when it has vast assets depends on its capital structure. If cash balances and current assets of a corporation are larger than fixed assets, it means the corporation has vast liquid assets and is a potential candidate to pay dividends.

\section{METHODOLOGY}

\subsection{Data}

We used the Indonesian listed financial institutions, which consisted of 64 firms, 26 banks and 38 other financial institutions, during the period 2007 to 2016 . The data for each financial institution were captured from the firm's website. The sources for the macroeconomics such as GDP growth and inflation rate was the website of the Indonesian Center for Statistics Biro (BPS)

\subsection{Empirical Model}

This study used a static data panel regression model, where the dependent variable is dividend payout. Thus our model is as follows:

$$
\begin{aligned}
\text { Div }_{i t}= & \propto+\beta_{1} \text { Ownership }_{i t}+\beta_{2} \text { Liquidity }_{i t}+\beta_{3} \text { Size }_{i t}+\beta_{4} \text { Lev }_{i t} \\
& +\beta_{5} G D P_{i t}+\beta_{6} \operatorname{Inf}_{i t}+\varepsilon_{i t}
\end{aligned}
$$

$D i v=$ dividend pay-out, the ratio of yearly dividend payments divided by net earnings. Ownership is the ownership concentration, divided into three categories. First an insider is an owner with $25 \%$ or more of the stock in a bank or $50 \%$ or more of the stock in a public corporation. Second, a stable investor owns less than $24 \%$ of the stock in a bank and less than $49 \%$ in a public corporation. Third, a market (public) investor owns at least 5\% of the stock. Liquidity of the company is measured using the ratio of total retained earnings over total equity. An alternative measurement is retained 
earnings divided by total assets. Total assets is applied to measure the size of the company. The firm's leverage is the ratio of total liability over total assets.

Table 1: Summary of Variables

\begin{tabular}{|c|c|c|}
\hline Variable & Description & Source \\
\hline $\begin{array}{l}\text { Dependent } \\
\text { Variable }\end{array}$ & Dividend Payment & $\begin{array}{l}\text { Yearly corporation dividend divided by net } \\
\text { earnings (Esqueda, 2016; Fama \& French, } \\
\text { 2000). }\end{array}$ \\
\hline \multirow[t]{6}{*}{ Variables } & $\begin{array}{l}\text { Corporate Governance: } \\
\text { Ownership concentration } \\
\text { (Source: Esqueda, 2016; } \\
\text { Heugens et al., 2008; } \\
\text { Spamann, 2010). }\end{array}$ & $\begin{array}{l}\text { Indicates the aggregate percent stock } \\
\text { ownership of insiders, stable investors, and } \\
\text { market investors (see text for definition). }\end{array}$ \\
\hline & & $\begin{array}{l}\text { RE/TE (DeAngelo et al., 2005). } \\
\text { RE/TA (DeAngelo et al., 2005). }\end{array}$ \\
\hline & $\begin{array}{l}\text { Corporate Liquidity } \\
\text { Retained earnings } \\
\text { as Total Equity } \\
\text { and as Total Assets }\end{array}$ & $\begin{array}{l}\text { Capital size: Equals the log of total assets in } \\
\text { Rupiah (Esqueda, 2016; Fama \& French, } \\
\text { 2000; DeAngelo et al., 2005). }\end{array}$ \\
\hline & Corporate size & $\begin{array}{l}\text { Leverage equals the ratio of total liabilities to } \\
\text { total assets (DeAngelo et al., 2005). }\end{array}$ \\
\hline & & Annual GDP growth percentage. \\
\hline & $\begin{array}{l}\text { Corporate Liquidity } \\
\text { Leverage }\end{array}$ & Annual inflation percentage. \\
\hline \multirow{2}{*}{$\begin{array}{l}\text { Control } \\
\text { Variables }\end{array}$} & GDP Growth & \\
\hline & Inflation & \\
\hline
\end{tabular}

\section{RESULTS AND DISCUSSION}

\subsection{Descriptive Statistics}

Table 2 presents the descriptive statistics. The average pay-out ratio is 15 percent and maximum is 586 percent. The average number of insider owners is 55 percent, stable owners is 49 percent, and market owners is 25 percent. The median percentage retained earnings over total equity is 7 percent. Additionally, this industry is characterized by higher leverage' the average number is 73 percent of assets financed by outsiders. 
Table 2: Descriptive Statistics

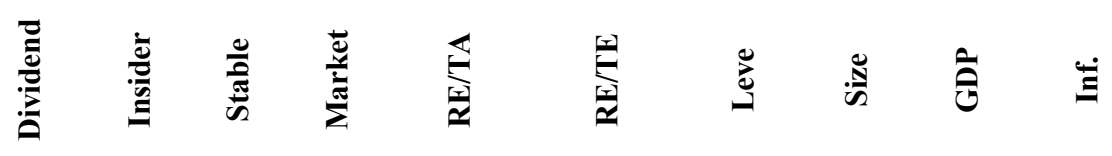

\begin{tabular}{lcccccccccc}
\hline Mean & 0.15 & 0.55 & 0.49 & 0.25 & -0.02 & -0.67 & 0.73 & 28.9 & 0.06 & 0.06 \\
Median & 0.00 & 0.59 & 0.08 & 0.25 & 0.07 & 0.38 & 0.77 & 29 & 0.06 & 0.06 \\
Max & 5.86 & 0.99 & 0.93 & 0.83 & 0.86 & 11.98 & 36.10 & 35 & 0.06 & 0.10 \\
Min & -6.15 & 0.00 & 0.00 & 0.00 & -13.99 & -135.95 & 0.001 & 24 & 0.04 & 0.04 \\
Std. Dev. & 0.57 & 0.30 & 5.17 & 0.16 & 0.89 & 9.54 & 1.47 & 2.48 & 0.01 & 0.02 \\
\hline \hline
\end{tabular}

\subsection{Empirical Results}

Table 3 displays the summary of the regression model estimation, which was estimated with the robust least squares method. Column 1 shows RE/TE as a measurement of the firm's liquidity, whereas in column 2 , the ratio RE/TA is used as the alternative measurement of liquidity.

Table 3: Summary of The Regression Model Estimation

\begin{tabular}{lll}
\hline \hline & $\mathbf{R}$ & $\mathbf{2}$ \\
& $\mathbf{R E} / \mathbf{T E}$ & $\mathbf{R E} / \mathbf{T A}$ \\
\hline Insider Ownership & $-0.0005^{* * *}$ & -0.0187 \\
Stable Ownership & $(0.0111)$ & $(0.2556)$ \\
& -0.0001 & -0.0002 \\
Market Ownership & $(0.3849)$ & $0.7394)$ \\
& $0.0009^{* * *}$ & 0.0437 \\
RE/TA & $(0.0086)$ & $(0.1285)$ \\
RE/TE & $0.0001^{* * *}$ & \\
& $(0.0142)$ & 0.0001 \\
Leverage & & $(0.7421)$ \\
Size & $-0.0025^{* * *}$ & 0.0017 \\
GDP & $(0.0000)$ & $(0.5288)$ \\
& $-0.0001^{* * *}$ & $0.0087^{* * *}$ \\
Inflation & $(0.0000)$ & $(0.0000)$ \\
& -0.0049 & 0.3450 \\
Constant & $(0.5286)$ & $(0.5881)$ \\
$N$ & 0.0019 & -0.2439 \\
$R^{2}$ & $(0.4808)$ & $(0.2684)$ \\
\hline \hline
\end{tabular}

Note: Robust regression analysis of the effect of ownership concentration and corporate liquidity on dividend payment policy of 640 banks and financial corporations from 2007 to 2016. p-values for robust regression model in parentheses. *** denote statistical significance at $1 \%$ level, $* *$ and $*$ mean significant at $5 \%$ and $10 \%$ levels, respectively. 


\subsubsection{The effect of ownership concentration on dividend payment policy}

Statistical panel data regression of insider ownership and market ownership shows a significant effect on dividend payment; however, stable ownership does not show a significant effect on dividend payment. Thus, financial corporations owned by insiders tend to pay less dividend. This is in accordance with the findings of Mulyani, Singh, and Mishra (2016) and Akbar and Bustaman (2019), who also analyse the effect of insider ownership of non-bank Indonesian corporations. It is a signal that there is disgorging cash flow by the insiders and management when distribution control is low (Jensen, 1986). With minority owners or public owners demanding more dividend payment from the company, it is shown from the positive sign of market ownership in Table 3 , that the higher the proportion of individual ownership the stronger the control from the market, causing the firm to pay more dividend to the owner. Thus, this result is in line with Jensen and Meckling (1976), who stated that the managerial opportunism or expropriation by controlling shareholders can be limited by the expenditure of resources on monitoring activities by market stockholders.

\subsubsection{The effect of liquidity (retained earnings) dividend by total assets (corporate profit) on dividend payment policy}

The ratio of RE/TA shows positive impact on dividend payment. Higher reserves in equity increase the ability of firms to pay more dividends. Corporations adopt dividend policies that best fit where they are currently in their life cycles. This result supports DeAngelo et al.,'s (2006) finding, that the probability of a corporation paying dividends increases with the relative amount of earned equity in its capital structure. The proportion of dividend payers is high when earned equity is a large fraction of total assets, and decreases as RE/TA declines. The results also indicate that a corporation's earned/contributed capital mix (not its total equity, but also debt-to-equity mix) is a key determinant of its decision to pay or not pay dividends. The more mature firms with ample cumulative profits tend to have high proportion of retained earnings and that makes them largely self-financing. Hence, this type of firm becomes a good candidate to pay dividends.

\subsubsection{The effect of leverage, size on dividend payment}

The results show that leverage affects dividend payment negatively. Firms with large leverage tend to pay less dividend. This result contradicts De Angelo et al., (2005) study. Financial institutions are characterized by higher leverage, that should pay more interest expenses, thus from this point of view, bank and other financial institutions will not consider paying dividends if the cost of paying depositors is high. Additionally, larger banks tend to pay lower dividends, reflected in the negative sign of the regression coefficient. This might occur because larger banks need to finance their higher operating costs; they have more branches and many employees, which makes them not efficient in managing their operating cash flows. Consequently, this type of firm pays lower dividends. This result is in line with the findings of previous studies, such as Gonzalez, Molina, Pablo, and Rosso (2016), Hwang, Kim, Park, and Park (2013), and Faccio, Lang, and Young (2001). 


\section{CONCLUSION}

The ownership structure of banking and financial institutions is a corporate governance mechanism that determines these firms' dividend policy. As discussed in Jensen (1986) and Jensen and Meckling (1976), dividend payment is also a control that can be used in firms to reduce the conflict of interest between managers and owners of a company. Dividend payment may decrease the availability of a firm's cash flow, which could reduce management discretion to use money for its own benefit an unfavorable investment (see Easterbrook, 1984).

Concentration of ownership in a large group or individual causes loose control in the company, as management is appointed by the owner and dividend policy decided by the majority shareholder, thus the payment of dividend may benefit the majority owner. They have the ability to drain the firm's cash flow for their own benefit and pay lower dividends to minority shareholders. Our findings reveal that insiders as majority owner tend to pay lower dividends; this is a signal that insiders are exploiting cash flow at the cost of minority shareholders in Indonesian banking and financial institutions. Thus, close attention from the regulator and financial services authority is needed to protect the minority shareholders.

A good signal for investors from these results is that the banking and finance industry supports the life cycle theory, where a higher proportion of reserve (retained earnings) in equity of banks can be used to pay higher dividends. Additionally, when the market ownership increases, control of the firm from the market increases, and the expectation of dividend payments also increases. However, higher-leverage and larger-size banks tend to pay lower dividends. The higher cost of banking operation could be a supporting explanation for this phenomenon.

\section{REFERENCES}

Akbar, M. A. \& Bustaman, Y. (2019). Firm profitability, ownership structure and dividend policy on the Indonesian manufacturing companies. Pertanika Journal of Social Sciences \& Humanities, 27(S2), 1-16.

Bapepam \& LK. (2011). Keputusan Ketua Badan Pengawas Modal dan Lembaga Keuangan, No: Kep-264/BL/2011. Retrieved from https://www.martinaberto.co.id/download /Peraturan_Bapepam/IX.H.1_Pengambilalihan_Perusahaan_Terbuka.pdf

Coffee, J. C. (2002). Racing towards the top: The impact of cross-listings and stock market competition on international corporate governance. Columbia Law Review, 102(7), 17571831.

DeAngelo, H., DeAngelo, L., \& Stulz, R. M. (2006). Dividend policy and the earned/contributed capital mix: A test of the life cycle theory. Journal of Financial Economics, 81, 227-254.

Esqueda, O. A. (2016). Signalling, corporate governance, and the equilibrium dividend policy. Quarterly Review of Economics and Finance, 59, 186-199.

Faccio, M., Lang, I., \& Young, L. (2001). Dividends and expropriation. American Economics Review, 91, 54-78.

Fama, E. F. \& French, K. R. (2000). Disappearing dividends: Changing firm characteristics or lower propensity to pay? Journal of Financial Economics, 60, 3-43.

Financial Times. (2018). Definition of Ownership Concentration. Retrieved from http:// Lexicon.ft.com/Term?term $=$ ownership-concentration 
Gillan, S. L. (2006.) Recent developments in corporate governance: An overview. Journal of Corporate Finance, 12, 381-402.

Gonzalez, M., Molina , C., Pablo, E., \& Rosso, J. (2016). The effect of ownership concentration and composition on dividend: Evidence from Latin America. Emerging Market Review, $30,1-18$.

Gugler, K. \& Burcin Yurtoglv, B. (2003). Corporate governance and dividend payout policy in Germany. European Economic Review, 47, 731-758.

Heugens, P. P. M. A. R, Van Essen, M. \& (Hans) Van Oosterhout, J. (2008). Meta-analyzing ownership concentration and firm performance in Asia: Towards a more fine-grained understanding. Asia Pacific Journal of Management, 26, 481-512. doi:10.1007/s10490008-9109-0

Hwang, L., Kim, H., Park, K., \& Park, R. (2013). Corporate governance and payout policy: Evidence from Korean business groups. Pacific Basin Finance Journal, 24, 179-198.

Jensen, M. C. (1986). Agency costs of free cashflow, corporate finance and takeovers. American Economic Review, 76(2), 323-329.

Jensen, M. C. \& Meckling, W. H. (1976). Theory of the firm: Managerial behavior, agency costs and ownership structure. Journal of Financial Economics, 3(4), 305-360.

Koussis, N., Martzoukos, S. H., \& Trigeorgis, L. (2016). Corporate liquidity and dividend policy under uncertainty. Journal of Banking and Finance, 75, 200-214. doi: 10.1016/j.jbankfin.2016.11.015

LaPorta, R., Lopez-De-Silanes, F., Shleifer, A., \& Vishny, R. W. (2000). Agency problems and dividend policies around the world. Journal of Finance, 55(1), 1-33.

Mitton, T. (2004). Corporate governance and dividend policy in emerging markets. Emerging Markets Review, 5, 409-426.

Mulyani, E., Singh, H., \& Mishra, S. (2016). Dividends, leverage, and family ownership in emerging Indonesian markets. Journal of International Financial Markets, Institutions \& Money, 43, 16-29.

Petrasek, L. (2012). Do transparent firms pay out cash to shareholders? Evidence from international cross-listings. Financial Management, 41(3), 615-636.

Ross, S. A., Westerfield, R. W., Jaffe, J., Lim, J., Tan, R., \& Wong, H. (2015). Corporate Finance. New York, NY: McGraw-Hill.

Setia-Atmaja, L., Tanewski, G., \& Skully, M. (2009). The role of dividend, debt and board structure in governance of family controlled companies. Journal of Business Finance \& Accounting, 36(7-8), 863-898.

Spamann, H. (2010). The “Antidirector Rights Index" revisited. Review of Financial Studies, 23(2), 467-486. doi:10.1093/rfs/hhp067

Walsh, J. P., \& Seward, J. K. (1990). On the efficiency of internal and external corporate control mechanisms. Academy of Management Review, 15, 421-458.

World Bank. (2001). Annual World Bank Conference on Development Economics 2000. Washington, DC: Author. 